EGU2020-4958

https://doi.org/10.5194/egusphere-egu2020-4958

EGU General Assembly 2020

(c) Author(s) 2020. This work is distributed under

the Creative Commons Attribution 4.0 License.

\title{
Vertical interval dynamics of greenhouse gases in groundwater (Hesbaye chalk aquifer, Belgium)
}

\author{
Olha Nikolenko ${ }^{1,2}$, Cedric Morana ${ }^{2}$, Bernard Taminiau ${ }^{3}$, Alberto V. Borges ${ }^{2}$, Tanguy Robert ${ }^{1,4}$, \\ Pascal Goderniaux ${ }^{5}$, Maxime Duvivier ${ }^{1}$, and Serge Brouyère ${ }^{1}$ \\ ${ }^{1}$ University of Liège, Urban and Environmental Engineering department, Hydrogeology and Environmental Geology, \\ Aquapôle, 4000 Liège, Belgium, (o.nikolenko@uliege.be) \\ ${ }^{2}$ Chemical Oceanography Unit, University of Liège, Liège, Belgium \\ ${ }^{3}$ Department of Food Sciences-Microbiology, FARAH, Faculty of Veterinary Medicine, University of Liège, 4000, Liège, \\ Belgium \\ ${ }^{4}$ F.R.S.-FNRS (Fonds de la Recherche Scientifique), 1000 Bruxelles, Belgium \\ ${ }^{5}$ Geology and Applied Geology, Polytech Mons, University of Mons, Mons, Belgium
}

Increase in the concentration of greenhouse gases (GHGs) in the atmosphere threatens the existence of many ecosystems and their inhabitants. Agricultural activities contribute up to $70 \%$ of total anthropogenic emission of nitrous oxide $\left(\mathrm{N}_{2} \mathrm{O}\right)$, one of the GHGs, which is characterized with the highest global warming potential and contributes to stratospheric ozone depletion. Our study presents the results obtained from the recent field and lab activities carried out in order to obtain better insight into the factors that define the presence of $\mathrm{N}_{2} \mathrm{O}$ in groundwater. Previous large scale investigations, performed in the Hesbaye chalk aquifer in Eastern Belgium, suggested that the concentration of $\mathrm{N}_{2} \mathrm{O}$ in the aquifer depends on different, possibly overlapping biochemical processes such as nitrification, denitrification and/or nitrifier-denitrification. This study explored the occurrence of biochemical stratification in the same aquifer and its impact on $\mathrm{N}_{2} \mathrm{O}$ production and consumption mechanisms. For this purpose low flow sampling technique was applied at different depth intervals to obtain better insight into the extent of oxic and anoxic zones and variability of concentrations of GHGs along the vertical profile. Collected groundwater samples were analyzed for the range of hydrochemical parameters as well as $\mathrm{NO}_{3}{ }^{-}, \mathrm{N}_{2} \mathrm{O}, \mathrm{H}_{2} \mathrm{O}$ and $\mathrm{B}$ isotopes signatures and $\mathrm{N}_{2} \mathrm{O}$ isotopomers. Afterwards, rates of nitrification and denitrification processes were estimated based on short-term incubations of collected groundwater amended with $\mathrm{NO}_{3}^{-}$and $\mathrm{NH}_{4}^{+}$compounds labeled with heavy ${ }^{15} \mathrm{~N}$ isotope. In addition, in order to characterize the dynamics of ongoing biogeochemical processes, polymerase chain reaction (PCR) tests for detection of the activity-specific enzymes in the aquifer were performed. Such studies help to clarify which conditions are more prone to the accumulation of high concentrations of GHGs in aquifers and better constrain models which estimate local and regional GHGs budgets.

Acknowledgments

This project has received funding from the European Union's Horizon 2020 research and innovation programme under the Marie Skłodowska-Curie grant agreement No 675120. 
How to cite: Nikolenko, O., Morana, C., Taminiau, B., Borges, A. V., Robert, T., Goderniaux, P., Duvivier, $M$., and Brouyère, $S .:$ Vertical interval dynamics of greenhouse gases in groundwater (Hesbaye chalk aquifer, Belgium), EGU General Assembly 2020, Online, 4-8 May 2020,

EGU2020-4958, https://doi.org/10.5194/egusphere-egu2020-4958, 2020 